ISSN: 1907-9931 (print), 2476-9991 (online)

\title{
KOMUNITAS IKAN KARANG DI PERAIRAN TAMAN WISATA ALAM (TWA) BATUANGUS, KOTAMADYA BITUNG, PROVINSI SULAWESI UTARA
}

\author{
REEF FISH COMMUNITY IN THE BATUANGUS NATURE PARK, MUNICIPALITY OF BITUNG, NORTH \\ SULAWESI PROVINCE
}

\section{Fakhrizal Setiawan}

Wildlife Conservation Society-Indonesia Marine Program

Corresponding author e-mail: Setiawan.rizal@gmail.com

Received: January 25, 2016/Accepted: March 30, 2016

\begin{abstract}
Research was conducted at 4 point dive sites in TWA Batuangus and 1 tourist sites as a comparison site to see the condition of coral reef ecosystems that include coral cover and reef fish communities' information. Live coral cover obtained generally show in moderate category (25 to 49.9\%). Coral genus recorded in 33 transects genus were 27 genera of hard corals and 6 genus of soft corals. Reef fish recorded consists of 195 species of reef fish and 37 families. Locations in the TWA Batuangus which have relatively good conditions, is Batu Beach location where had higher abundance and biomass compared to other locations. Magic Rock seen better than that of TWA Batuangus, based from the condition of coral and targeted fish. This is most likely because the location of TWA Batuangus is the fishing area for the surrounding communities while Magic Rock is became one of the important diving spot in the Lembeh Strait. Reef fish community structure based on ecological indices are in unstable condition $\left(\mathrm{H}^{\prime}\right.$ were in low to moderate, $E$ were depressed until labile and $C$ were low). The similarity of reef fish species grouping Hall Batuangus separated with other sites because of the characteristics of the location in the form of semi-enclosed bays where the circulation of currents which do not enter into the bay which makes limiting the distribution of coral and fish.
\end{abstract}

Keywords: abundance, biomass, Batuangus, reef fish community structure, wildlife nature.

\begin{abstract}
ABSTRAK
Penelitian sebanyak 4 titik penyelaman di TWA Batuangus dan 1 lokasi wisata sebagai pembanding dilakukan untuk melihat kondisi ekosistem terumbu karang yang meliputi informasi tutupan karang dan komunitas ikan karang. Tutupan karang hidup yang didapatkan menunjukkan umumnya berada pada kategori sedang (25-49,9\%). Genus karang yang tercatat masuk di dalam transek sebanyak 33 genus yang terdiri dari 27 genus karang keras dan 6 genus karang lunak. Ikan karang yang dicatat/ditemukan dalam survei derah dangkal ini terdiri dari 195 species ikan karang yang termasuk dalam 37 famili. Lokasi di dalam TWA Batuangus yang memiliki kondisi relatif baik yaitu di lokasi Pantai Batu dimana memiliki kelimpahan dan biomassa terbaik dibanding lokasi lainnya. Lokasi pembanding Magic Rock sedikit lebih baik daripada TWA Batuangus, jika dilihat dari kondisi karang serta ikan target. Hal ini kemungkinan karena lokasi TWA Batuangus menjadi daerah penangkapan ikan bagi masyarakat sekitar, sedangkan Magic Rock yang menjadi salah satu spot penyelaman penting di Selat Lembeh. Struktur komunitas ikan karang berdasarkan indeks ekologinya berada dalam kondisi labil ( $H^{\prime}$ masuk rendah hingga sedang, E tertekan hingga labil dan $C$ yang rendah). Kesamaan species ikan karang mengelompokkan site Hall Batuangus terpisah dengan site lainnya karena karakteristik lokasi yang berupa teluk semi tertutup dimana sirkulasi arus yang tidak masuk kedalam teluk yang menjadikan pembatas distribusi karang dan ikan yang ada di dalamnya.
\end{abstract}

Kata kunci: biomassa, Batuangus, kelimpahan, struktur komunitas ikan karang, Taman Wisata Alam. 


\section{PENDAHULUAN}

Taman Wisata Alam (TWA) Batu Angus secara administratif termasuk Desa Kasuari, Kecamatan Makawidey, Kotamadya Bitung, Propinsi Sulawesi Utara. TWA Batu Angus ditetapkan berdasarkan Surat Keputusan Menteri Pertanian No. 1049/Kpts/Um/12/81 tanggal 24 Desember 1981 dengan luas $635 \mathrm{Ha}$ dan secara geografis terletak pada 0130'-0134' Lintang Utara dan 12514'39"-12506'46" Bujur Timur. Dalam sejarahnya TWA Batuangus terbentuk akibat letusan gunung berapi sekitar tahun 1839 dan lava yang mengalir mengeras membentuk batuan hitam hingga ke persisirnya. Kejadian ini menimbulkan ekosistem unik baru akibat perubahan ekologis di perairannya.

Lokasi TWA Batuangus yang berada di kawasan Selat Lembeh menjadi salah satu lokasi menyelam popular di Sulawesi Utara. Informasi mengenai kondisi perairan TWA Batuangus dimana areanya merupakan ekosistem terumbu karang hingga saat ini belum pernah dilakukan survei ekologi sebelumnya, sehingga informasi yang dihasilkan dapat dijadikan pegangan / rujukan serta baseline data untuk pengembangan kedepannya. Informasi mengenai seluk beluk kehidupan ikan karang ternyata masih belum banyak diketahui yang meliputi pola sebaran spasial, temporal, struktur komunitas dan lain sebagainya (Adrim, 2007). Adapun tujuan penelitian ini yaitu untuk mendapatkan informasi terkini tentang kondisi terumbu karang dan komunitas ikan karang di TWA Batuangus.

\section{MATERI DAN METODE}

\section{Lokasi dan waktu kegiatan}

Lokasi kegiatan survei terumbu karang dan ikan karang ini meliputi daerah pesisir di kawasan TWA Batuangus sebanyak empat site penyelaman serta satu lokasi pembanding di daerah pariwisata disampingnya. Survei tersebut dilakukan pada bulan Agustus 2013. Peta lokasi survei disajikan pada Gambar 1 di bawah ini.

Tabel 1. Koordinat lokasi penelitian di TWA Batuangus.

\begin{tabular}{clll}
\hline Zonasi & Lokasi & Lintang & Bujur \\
\hline Pembanding & Magic Rock & $01^{0} 29^{\prime} 12,7^{\prime \prime}$ & $125^{\circ} 14^{\prime} 28,4^{\prime \prime}$ \\
& Hall Batuangus & $01^{\circ} 30^{\prime} 26,2^{\prime \prime}$ & $125^{\circ} 14^{\prime} 46,7^{\prime \prime}$ \\
& Jiko Beringin & $01^{\circ} 31^{\prime} 30,6^{\prime \prime}$ & $125^{\circ} 14^{\prime} 9,4^{\prime \prime}$ \\
\multirow{2}{*}{ TWA } & Pantai Batu & $01^{\circ} 31^{\prime} 9,4^{\prime \prime}$ & $125^{\circ} 14^{\prime} 23,1^{\prime \prime}$ \\
& Pantai Jaga & $01^{\circ} 30^{\prime} 35,6^{\prime \prime}$ & $125^{\circ} 14^{\prime} 46,9^{\prime \prime}$ \\
\hline
\end{tabular}

Pengambilan data di luar TWA Batuangus dilakukan untuk membandingkan kondisi terumbu karang dan ikan di daerah yang dikelola BKSDA Sulawesi Utara dengan daerah yang dikelola oleh operator wisata yang berada di Selat Lembeh. Hal ini sangat penting untuk menjelaskan bahwa upaya pengelolaan memang diperlukan supaya sumberdaya yang ada di wilayah tersebut dapat memberikan hasil yang optimal. Penentuan survei point umumnya disesuaikan dengan kondisi keterwakilan lokasi TWA. Jumlah titik survei untuk pengamatan terumbu karang dan ikan ditetapkan di lokasi yang mewakili kondisi perairan ekosistem terumbu karang di TWA Batuangus. 


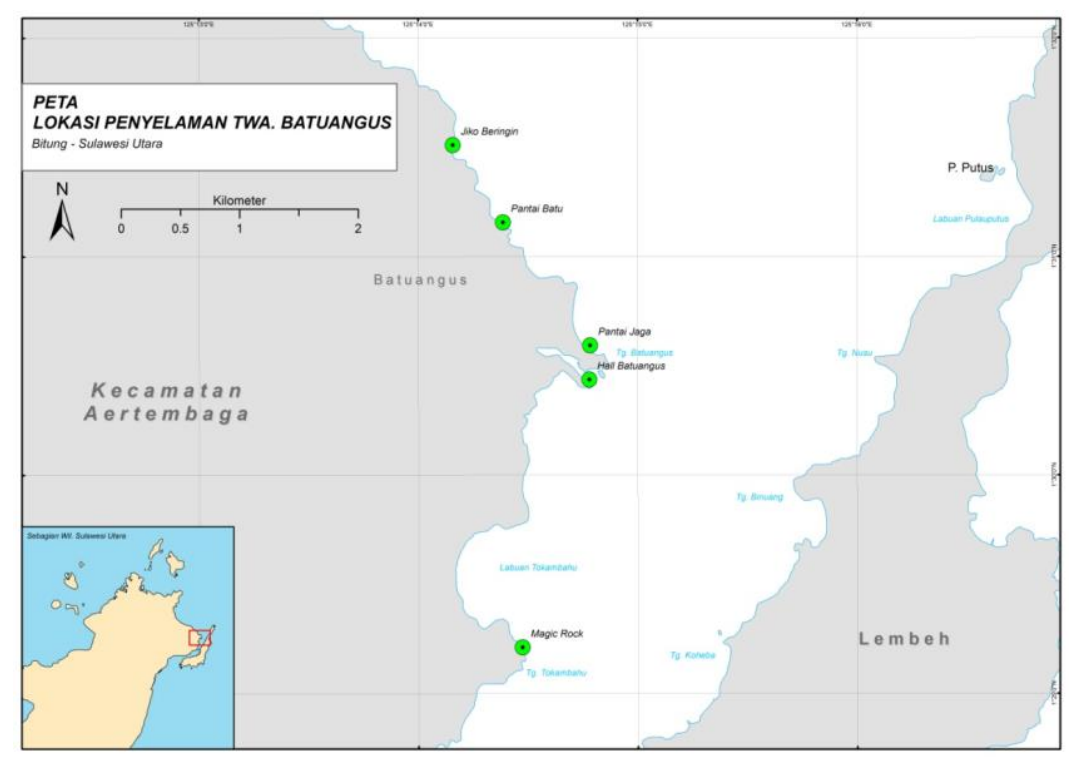

Gambar 1. Peta lokasi survei ekologi di TWA Batuangus.

\section{Metode survei terumbu karang dan ikan karang}

Metode pencatatan tutupan karang dan makro benthos, menggunakan transek titik yaitu point intercept trancet (PIT) sepanjang 50 meter sebanyak 3 kali ulangan pada dua kedalaman yaitu dangkal (2 - 4 meter) dan dalam (8 - 10 meter) (Marnane et al., 2003). Ikan karang menggunakan metode visual sensus pada transek yang sama dengan karang, transek pengamatan menggunakan garis maya yang ditarik paralel dengan transek garis membentuk luasan persegi panjang. Transek jenis ini dikenal dengan transek sabuk (Hill and Wilkinson, 2004).

\section{Pengolahan dan analisis data}

Analisis data tutupan karang: $\quad \%$ kemunculan komponen $=\frac{\text { jumlah tiap komponen }}{100(\text { total komponen })} \times 100 \%$

Analisis ikan karang meliputi:

Kelimpahan komunitas terpilih dapat dihitung dengan rumus (Odum, 1971): $\mathbf{X} \mathbf{i}=\frac{\mathbf{n i}}{\mathbf{A}}$

dimana: $\mathrm{Xi}=$ kelimpahan komunitas terpilih $\mathrm{ke}-\mathrm{i}$ (individu/koloni per meter persegi); $\mathrm{ni}=$ jumlah total komunitas terpilih pada stasiun pengamatan ke-i; $\mathrm{A}=$ luas transek pengamatan.

Biomassa ikan karang:

Data panjang ikan $(\mathrm{cm})$ kemudian dikonversi ke dalam berat $(\mathrm{kg})$ dengan menggunakan rumus hubungan panjang dan berat ikan untuk tiap spesies (Bohnsack and Harper, 1988; Kulbicki et al., 2005): $\mathbf{W}=\mathbf{a} \times \mathbf{L}^{\mathbf{b}}$,

dimana: W: berat (gr); L : panjang total (cm); a \& b : indeks spesifik (per species).

Struktur komunitas ikan karang (Ludwig \& Reynolds, 1988)

meliputi:

indeks keanekaragaman Shanon-Weiner: $\mathbf{H}^{\prime}=-\sum_{i=1}^{S}$ pi In pi,

indeks kesamaan: $\mathbf{E}=\frac{\mathrm{H}}{\mathbf{H} \text { maks }}$

dan indeks dominansi: $\mathbf{D}=\sum_{i=1}^{S} \mathbf{p i}^{2}$. 
Untuk mengetahui tingkat pengelompokan berdasarkan kesamaan species ikan karang digunakan Indeks kesamaan Bray-Curtis (Krebs, 1989):

$\mathbf{B}=\frac{\Sigma(X i j-X i k)}{\Sigma(X i j-X i k)} ;$ dimana: $B=$ Pengukuran Ketidaksamaan Bray-Curtis, $X_{i j}, X_{i k}=j u m l a h$ individu dalam species $\mathrm{i}$ dalam tiap sampel, $\mathrm{i}, \mathrm{j}=$ baris dan kolom ke-1,2,3...x. Pengukuran indeks kesamaan Bray-Curtis dapat menggunakan rumus komplemen indeks pengukuran Bray-Curtis yaitu 1,0 - B (Krebs, 1989). Hasil perhitungan indeks Bray Curtis ditampilkan dalam bentuk dendogram. Pengolahan data menggunakan perangkat lunak MVSP (MultiVariate Statistical Package) ver.3.21.

\section{HASIL DAN PEMBAHASAN}

\section{Terumbu karang}

\section{Komposisi tutupan substrat dasar}

Kondisi substrat dasar dikelompokkan kedalam kategori yang terdiri dari karang keras dan karang lunak, alga, sponge, abiotik dan others. Karang hidup terdiri dari semua jenis karang pembentuk terumbu (hard corals) dan karang lunak (soft corals). Alga terdiri dari semua substrat yang telah diselimuti alga termasuk DC, sedangkan others terdiri dari semua jenis invertebrata bentik yang tidak tergolong karang. Substrat yang tergolong abiotik terdiri dari pasir, rubble (patahan karang kecil) dan batu.

Dari keseluruhan lokasi pengamatan di TWA Batuangus, karang keras dengan tutupan tertinggi terdapat di Jiko Beringin $(40,17 \%)$ dan terendah di Hall Batuangus $(25,67 \%)$ dengan rata-rata sebesar 45,1\%. Lokasi pembanding yaitu di Magic Rock memiliki tutupan karang paling tinggi dibandingkan seluruh lokasi TWA sebesar $44,5 \%$. Karang lunak dengan tutupan tertinggi sebesar 9,5\% terdapat di lokasi Pantai Jaga dan terendah terdapat di Hall Batuangus sebesar 4,33\%. Tutupan alga dalam hal ini terdiri dari makroalga dan DCA (death coral with algae) (contoh: Caulerpa, Padina, Sargassum, Halimeda, dll) tertinggi terdapat di lokasi Pantai Jaga $(14,83 \%)$ dan terendah di Hall Batuangus (12,33\%) (Gambar 2).

Komponen others dimana yang tercatat meliputi organism laut bentik non karang seperti (Linckia sp., Holoturoida, Crinoid, Tridacna sp., Diadema sp., dll) di lokasi tertinggi di lokasi Hall Batuangus (6\%) dan terendah terdapat di lokasi Pantai Batu (1,5\%). Terakhir untuk komponen abiotik umumnya didominasi oleh pasir di beberapa lokasi dan sedikit rubble dan batu. Komponen abiotik tertinggi terdapat di Hall Batuangus sebesar 51,67\% dan terendah di Jiko Beringin sebesar 40,67\% (Gambar 2).

Komposisi substrat dimana tutupan karang keras tertinggi menunjukan lokasi pembanding yaitu Magic Rock paling baik dimana alga dan komponen abiotik persentase tutupannya kecil. Hal ini menunjukan hamparan terumbu karang di daerah Pembanding sangat baik karena sebagian besar ditutupi oleh terumbu karang. Lokasi TWA Batuangus umumnya bersubstrat pasir dimana karang tumbuh mengelompok dan sulit tumbuh di daerah pasir yang memiliki tingkat sedimentasi yang tinggi. 
ISSN: 1907-9931 (print), 2476-9991 (online)

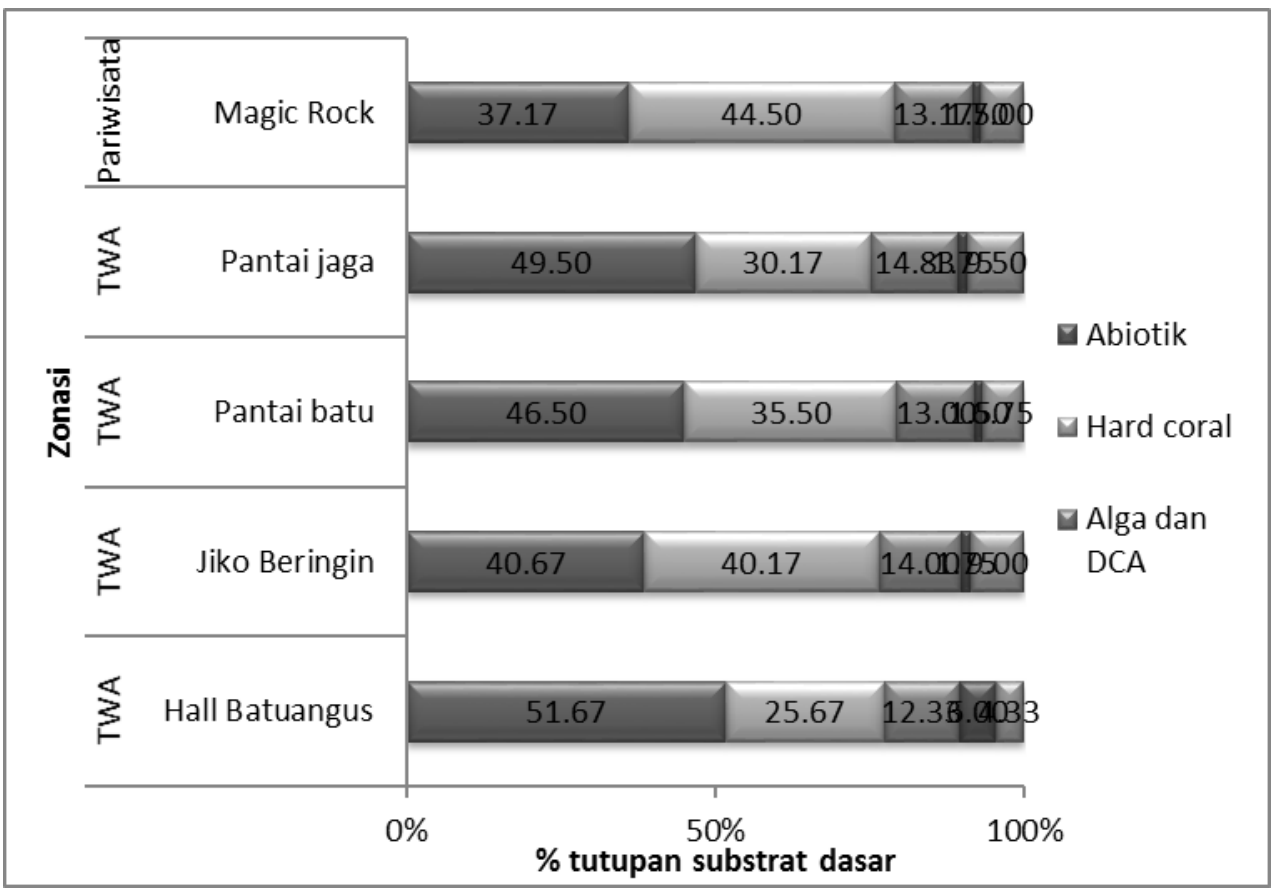

Gambar 2. Komposisi tutupan substrat dasar di TWA Batuangus.

\section{Tutupan karang hidup}

Genus karang yang tercatat masuk di dalam transek sebanyak 33 genus yang terdiri dari 27 genus karang keras dan 6 genus karang lunak. Persentase tutupan karang hidup dimana penggabungan dari data karang keras dan karang lunak berkisar antara $30-49,17 \%$ dengan ratarata sebesar 42,57\%. Berdasarkan KEPMEN LH No 4 tahun 2001 baik di TWA Batuangus maupun lokasi pembanding masuk dalam kategori sedang hingga baik dengan rata-rata masuk kategori sedang. Tutupan karang hidup tertinggi terdapat di lokasi pembanding yaitu Magic Rock $(51,50 \%)$ dan untuk tutupan tertinggi di TWA Batuangus terdapat di lokasi Jiko Beringin sedangkan untuk tutupan karang hidup terendah terdapat di Hall Batuangus (30\%) (Tabel 2 dan Gambar 3).

Tabel 2. Persentase tutupan karang di TWA Batuangus dan pembandingnya.

\begin{tabular}{clcl}
\hline Zonasi & Lokasi & \% Tutupan Karang & Kondisi \\
\hline \multirow{2}{*}{ Pembanding } & Magic Rock & 51.5 & Baik \\
& Hall Batuangus & 30 & Sedang \\
\multirow{3}{*}{ TWA } & Jiko Beringin & 49.17 & Sedang \\
& Pantai Batu & 42.25 & Sedang \\
& Pantai Jaga & 39.67 & Sedang \\
\hline
\end{tabular}

Secara keseluruhan lokasi TWA Batuangus masuk dalam kisaran sedang hal ini dikarenakan kondisi substrat dasar yang relatif pasir sehingga menjadi faktor pembatas untuk tumbuh dan berkembang menjadi koloni karang yang besar dimana karang membutuhkan substrat yang padat dan kompak untuk menempel. 


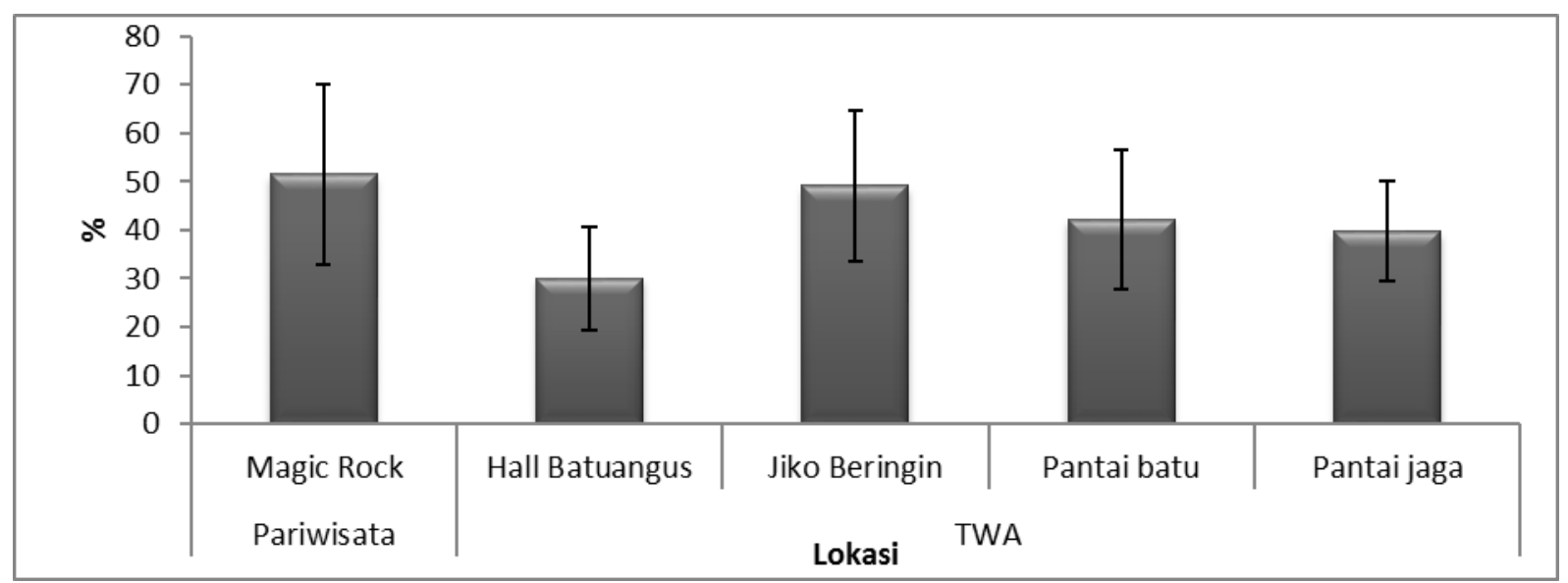

Gambar 3. Histogram rata-rata $( \pm$ SE) persentase tutupan karang hidup di TWA Batuangus.

\section{Ikan karang}

Ikan karang yang dicatat/ditemukan dalam survei di TWA Batuangus terdiri dari 195 species ikan karang yang termasuk dalam 37 famili dengan jumlah individu tercatat sebanyak 4392 individu. Umumnya ikan karang yang memiliki biomassa dan kelimpahan tertinggi dijumpai dalam keadaan berkelompok (schooling), hal inilah yang mengakibatkan beberapa data memiliki ketimpangan di beberapa lokasi. Untuk melihat sejauh mana famili ikan ini yang memiliki jumlah dan jenis mempengaruhi data serta ekosistemnya, maka analisis ditambahkan dengan kelimpahan dan biomassa sehingga dapat melihat kondisi ekosistemnya, apakah masih dalam kondisi baik atau tidak.

Keanekaragaman species ikan karang mempunyai hubungan yang erat dengan keberadaan terumbu karang di daerah tersebut. Tingkah laku ikan karang baik kecenderungan untuk berkelompok, mencari makan dan bertahan dari serangan predator tidak terlepas dari lingkungan yang berstruktur akibat bentuk terumbu yang komplek. Perbedaan dalam habitat dipengaruhi oleh aktivitas gelombang, arus, cahaya, ketersediaan alga, plankton dan makanan lain serta kelimpahan bentuk dan variasi koral termasuk struktur terlindung lainnya memberikan kombinasi variasi yang besar dalam kelompok ikan niche mereka.

\section{Kategori Ikan Karang}

Selama penelitian telah diperoleh 3 kelompok kategori ikan karang yaitu ikan indikator dari famili Chaetodontidae sebanyak 15 species, ikan mayor trofik sebanyak 135 species dari 24 famili dan ikan target sebanyak 44 species dari 14 famili.

\section{Ikan Indikator}

Ikan indikator dari family Chaetodontidae terdiri dari 2 species dari genus Heniochus, 1 species dari genus Forcipiger, 1 species dari genus Coradion dan 11 species dari genus Chaetodon. Di beberapa lokasi terlihat Chaetodon kleinii dijumpai cukup dominan (62,16\%) dari seluruh jenis ikan indikator. Hal ini mirip dengan penelitian Adrim et al, 1991 di kepulauan Seribu dimana species Chaetodon octofasciatus mendominasi secara extrim $(85,2 \%)$ dan jenis tersebut menyukai daerah yang relatif keruh.

Beberapa lokasi seperti Jiko Beringin (27 individu), Pantai Batu (30 individu) dan Magic Rock (35 individu) memiliki kelimpahan (total individu) cukup tinggi namun lokasi di Hall Batuangus dan Pantai Jaga cukup rendah. Hal ini sulit dijelaskan alasannya namun kemungkinan akibat kondisi lingkungan dimana di Hall Batuangus kondisinya yg berupa teluk dan kelimpahan karang dan ikan yang tidak banyak sehingga jenis ikan Chaetodontidae juga sedikit. Begitu pula di Pantai Jaga dimana kondisi substratnya berupa pasir dan batuan gunung dan karangnya yang mengelompok tidak menyebar merata yang menyebabkan kelimpahan ikan Chaetodontidae juga 
ISSN: 1907-9931 (print), 2476-9991 (online)

tidak banyak. Hasil penelitian di TWA Batuangus tidak memperlihatkan hubungan yang linier antara jumlah ikan Chaetodontidae dengan tutupan karang (Gambar 4). Hal ini juga sama dengan penelitian yang dilakukan Adrim, 2007 di Pulau Enggano, Provinsi Bengkulu.

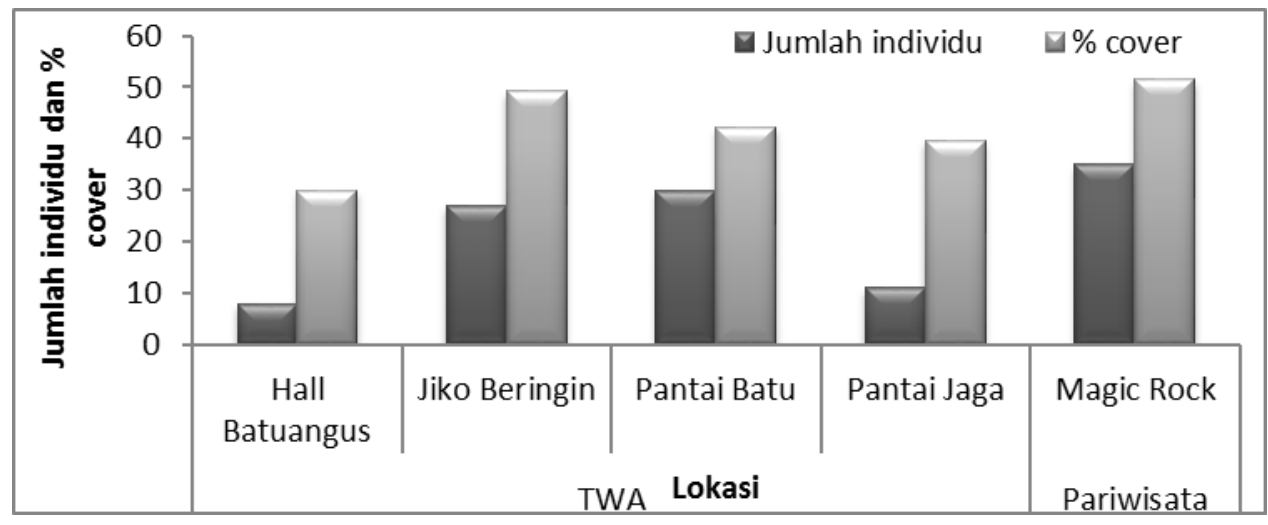

Gambar 4. Histogram jumlah individu ikan indikator dengan tutupan karang di TWA Batuangus.

\section{Ikan target}

Ikan Target yang merupakan target untuk penangkapan atau lebih dikenal juga dengan ikan ekonomis penting atau ikan konsumsi yang hidup berasosiasi dengan perairan karang. seperti: famili Seranidae, Lutjanidae, Caesionidae, Kyphosidae, Lethrinidae, Mullidae, Siganidae, Labridae (Cheilinus, Hemigymnus, Choerodon) dan Haemulidae (Terangi, 2004) . Kelimpahan family yang cukup dominan untuk ikan target yaitu family Caesionidae atau ikan ekor kuning/lolosi $(39,3 \%)$, Nemipteridae (10,9\%), Scaridae (10,5\%) dan Holocentridae (9,8\%). Terlihat ketimpangan yang cukup tinggi antara lokasi TWA dan pembanding dimana di lokasi pembanding (Magic Rock) memiliki kelimpahan ikan target yang tinggi (126 individu) dan sangat berbeda dengan di TWA Batuangus dengan site terendah di Hall Batuangus (21 individu). Hal ini dikarenakan lokasi Magic Rock merupakan lokasi penyelaman populer sehingga tingkat ancaman pengrusakan dan penangkapan dapat diminimalisir oleh resort-resort yang berada di sekitar Selat Lembeh.

Berbeda dengan perairan TWA Batuangus dimana nelayan dapat leluasa menangkap ikan disana. Umumnya masyarakat di sekitar TWA batuangus menangkap ikan untuk kebutuhan sehari-hari dan tidak diperjual belikan. Karena target utama nelayan disana adalah ikan-ikan pelagis (Cakalang, Tuna, dil) di laut lepas untuk dapat dijual ke industri yang terdapat di Kota Bitung. Namun melihat ketimpangan data yang didapat, kedepannya sangat direkomendasikan untuk memberikan batasan-batasan dalam menangkap ikan di sekitar perairan TWA Batuangus.

\section{Ikan mayor trofik}

Mayor trofik, yaitu species-species ikan yang tidak termasuk kedalam dua kelompok diatas dan umumnya belum diketahui peranannya kecuali dalam rantai makanan. Data semi kuantitatif diambil dengan menghitung secara taksiran, karena sebagian besar ikan-ikan yang termasuk kelompok ini hidup dalam kelompok besar (schooling). Umumnya ikan ini banyak dijadikan ikan hias (Pomacentridae, Apogonidae, Labridae, dll) (Terangi, 2004).

Kelompok ikan mayor trofik didominasi oleh ikan dari family Pomacentridae $(60,45 \%)$, Labridae $(15,5 \%)$ dan lainnya kurang dari $10 \%$. Species seperti Lepidozygus tapeinosoma, Chromis ternatensis, Cirrhilabrus cyanopleura, dan Plotosus lineatus memiliki kelimpahan tertinggi dibandingkan lainnya. Berdasarkan sebaran datanya lokasi di Pantai Batu memiliki kelimpahan (total individu) tertinggi (1444 individu) dan terendah di lokasi Pantai Jaga sebesar 402 individu. 


\section{Kelimpahan ikan karang}

Kelimpahan ikan karang di TWA Batuangus tertinggi terdapat di lokasi Pantai Batu sebesar 21.573, 33 Individu/Ha sedangkan di lokasi pembanding (Magic Rock) sebesar 13.303, 33 Individu/Ha (Gambar 5). Kelimpahan terendah untuk di dalam TWA terdapat di lokasi Pantai Jaga sebesar 6.426,67 Individu/Ha. Hasil survei memperlihatkan baik kelimpahan tertinggi maupun terendah sama-sama berada di TWA (Gambar 5). Kondisi karang yang mengelompok dan tidak tersebar merata menyebabkan ikan juga tidak terdistribusi merata di semua transek. Kondisi inilah yang umum terdapat di perairan TWA Batuangus. Pasir yang menjadi faktor pembatas distribusi karang sehingga ikan juga mengikuti pola distribusi karang yang ada.

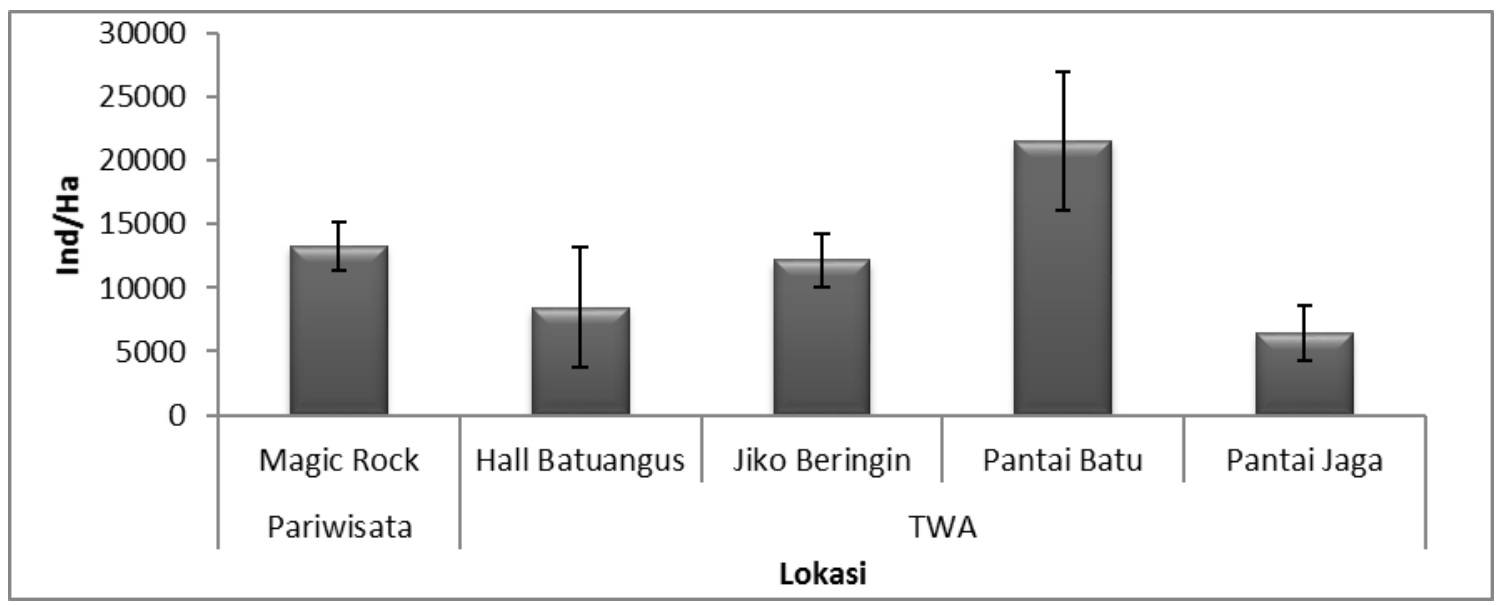

Gambar 5. Histogram rata-rata ( \pm SE) kelimpahan ikan karang di TWA Batuangus.

Kelimpahan tertinggi untuk kategori mayor trofik di TWA Batuangus terdapat di lokasi Pantai Batu sebesar 20.956,67 Individu/Ha dan terendah terdapat di Pantai Jaga sebesar 6.080 Individu/Ha. Pada bagian kategori ikan target, kelimpahan tertinggi terdapat di Pantai Batu sebesar 333,33 Individu/Ha dan terendah di Hall Batuangus sebesar 150 Individu/Ha. Sedangkan untuk ikan indikator tertinggi terdapat di lokasi Pantai Batu sebesar 233,33 Individu/Ha dan terendah di Hall Batuangus sebesar 140 Individu/Ha (Gambar 6).

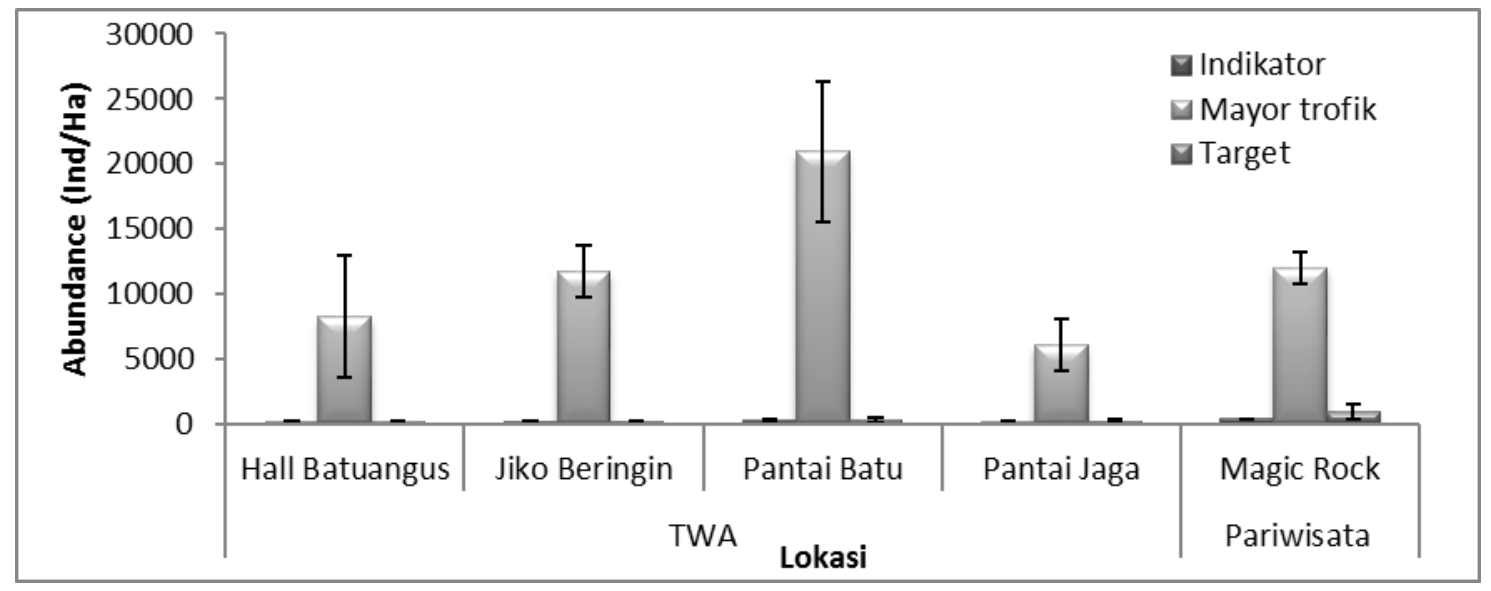

Gambar 6. Histogram rata-rata ( \pm SE) kelimpahan ikan karang per kategori di TWA Batuangus.

Umumnya kelimpahan didominasi oleh ikan dari kelompok mayor trofik dimana ikan belum diketahui secara pasti peranannya kecuali dalam rantai makanan. Secara keseluruhan lokasi Pantai Batu memiliki kelimpahan disemua katogori paling baik dibanding lokasi lain di TWA Batuangus dan pembanding di Magic Rock. Begitu pula ikan indicator dimana salah satu peran 
utamanya yaitu kelompok ikan ini memakan pucuk (tip) karang cabang yang lunak. Adanya pucuk lunak pada karang cabang menunjukkan karang tersebut bertumbuh baik karena kondisi lingkungan yang baik/sehat sehingga ada tidaknya ikan-ikan ini di sana mengindikasikan kondisi kesehatan lingkungan.

\section{Biomasa ikan karang}

Biomasa ikan karang tertinggi di TWA Batuangus terdapat di lokasi Pantai Batu sebesar 371,46 $\mathrm{Kg} / \mathrm{Ha}$ dan terendah terdapat di lokasi Hall Batuangus (Gambar 7). Lokasi pembanding memiliki biomassa cukup tinggi yaitu sebesar $359,33 \mathrm{Kg} / \mathrm{Ha}$. Lokasi Pantai Batu memiliki kelimpahan serta Biomassa tertinggi di semua lokasi di TWA Batuangus. Hal yang menjadi kekhawatiran adalah ikan karang di lokasi lain di dalam TWA Batuangus dimana biomassanya dan kelimpahan ikan karangnya rendah perlu perhatian khusus apakah ini merupakan kondisi alami atau dipengaruhi oleh aktifitas manusia.

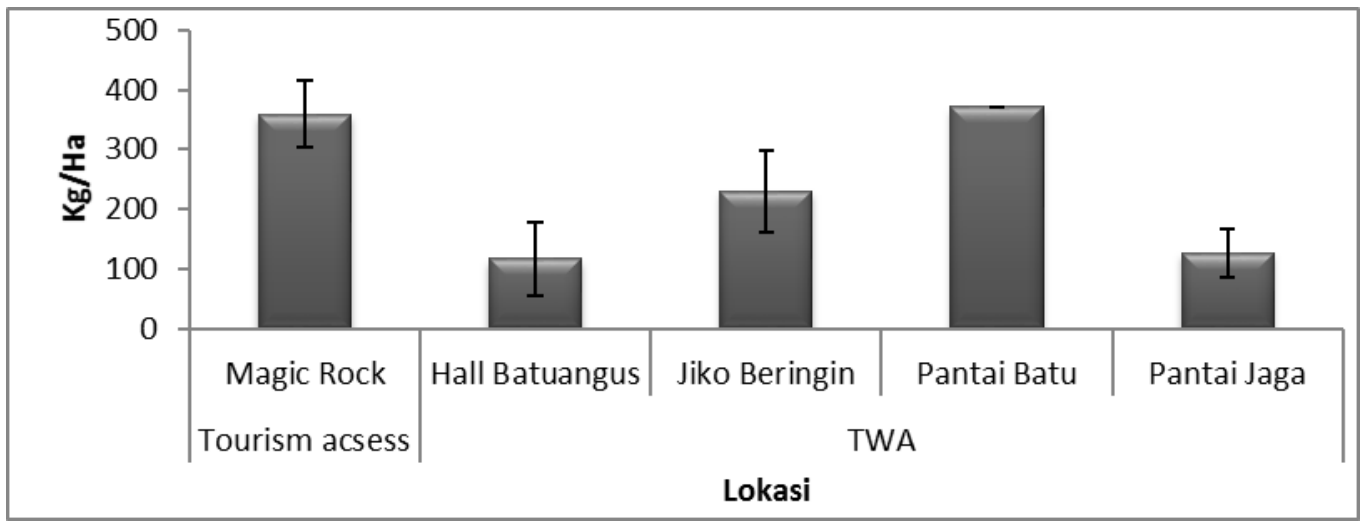

Gambar 7. Histogram rata-rata ( \pm SE) biomassa ikan karang di TWA Batuangus.

Biomassa ikan karang di TWA Batuangus berdasarkan kategorinya memperlihatkan bahwa untuk kategori ikan indikator tertinggi biomassanya terdapat di lokasi Pantai Batu sebesar 9,35 Kg/Ha dan terendah terdapat di lokasi Pantai Jaga sebesar $4,97 \mathrm{Kg} / \mathrm{Ha}$. Biomassa ikan mayor trofik tertinggi terdapat di lokasi Pantai Batu sebesar $332,51 \mathrm{Kg} / \mathrm{Ha}$ dan terendah terdapat di lokasi Hall Batuangus sebesar $73,69 \mathrm{Kg} / \mathrm{Ha}$. Sedangkan biomassa untuk ikan target tertinggi terdapat di lokasi Pantai Jaga sebesar 39,97 Kg/Ha (Gambar 8).

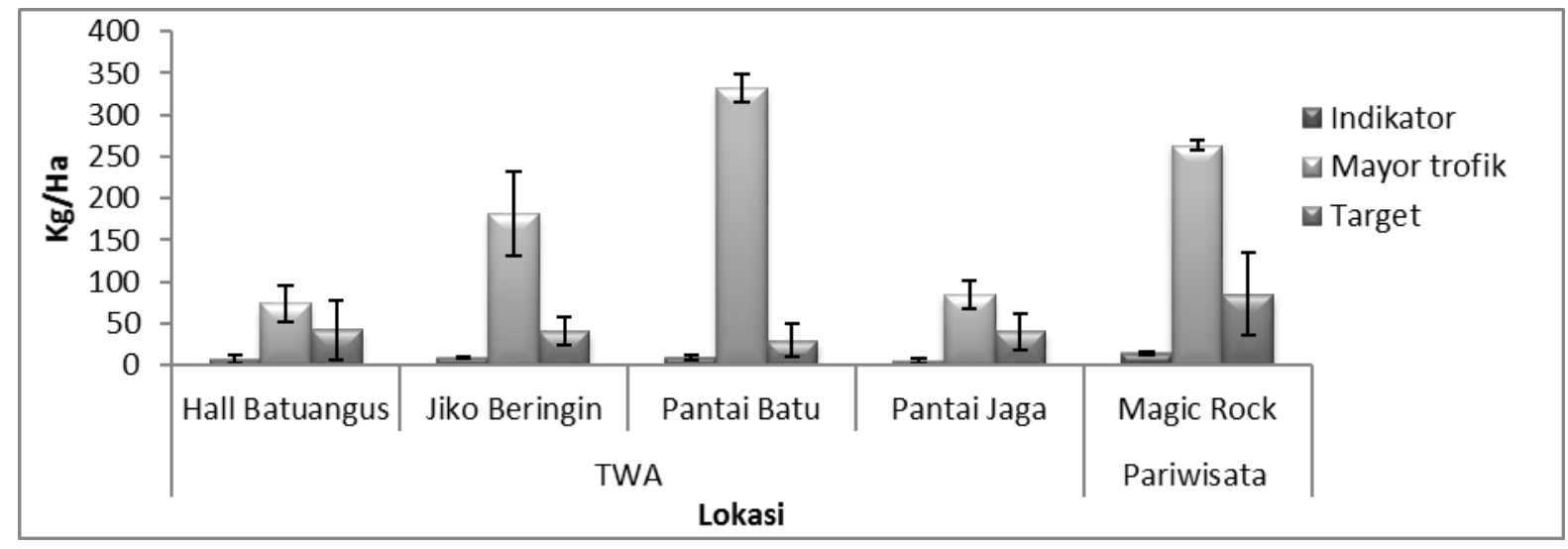

Gambar 8. Histogram rata-rata ( \pm SE) biomassa ikan karang di TWA Batuangus.

Jika kita membandingan dengan lokasi Magic Rock terlihat bahwa lokasi pembanding sedikit lebih baik dibandingkan dengan TWA Batuangus. Hal ini dapat dilihat dari kondisi karang serta ikan target yang ada. Hal ini kemungkinan lokasi TWA Batuangus menjadi daerah penangkapan 
ISSN: 1907-9931 (print), 2476-9991 (online)

ikan bagi masyarakat sekitar karena lokasinya yang bukan daerah spot penyelaman sehingga pengawasan kurang ketimbang lokasi wisata diamana selalu ada kegiatan penyelaman di lokasi pembanding.

\section{Indeks ekologi}

Hasil yang didapat selama penelitian menunjukkan indeks keanekaragaman berada pada kategori rendah hingga sedang, berkisar antara 1,88-2,667 dengan nilai rata-rata 2,404. Nilai keanekaragaman ini menunjukkan bahwa keseluruhan lokasi tidak ada yang memiliki keanekaragaman melimpah. Menurut Odum (1993) bahwa semakin besar nilai keanekaragaman $\left(\mathrm{H}^{\prime}\right)$ menunjukkan komunitas semakin beragam dan indeks keanekaragaman tergantung dari variasi jumlah species yang terdapat dalam suatu habitat. Nilai keanekaragaman tertinggi terdapat di site Jiko Beringin $(2,667)$ dan terendah di site Hall Batuangus $(1,880)$ (Gambar 9).

Nilai indeks kemerataan (E) menunjukkan kesetabilan sebuah komunitas. Nilai E dimana semakin mendekati 1 menunjukan komunitas semakin stabil dan jika semakin mendekati 0, maka komunitas semakin tertekan (Setyobudiandy et al., 2009 dalam Latuconsina et al., 2012). Nilai Indeks kemerataan tertinggi terdapat di site Jiko Beringin sebesar 0,548 dan terendah di site Hall Batuangus sebesar 0,461 dengan rata - rata 0,508. Nilai tersebut masuk dalam kategori tertekan hingga labil dan tidak ada satupun yang masuk dalam kategori stabil (Gambar 9). Menurut Odum (1993) indeks kemerataan (E) menggambarkan ukuran jumlah individu antar species dalam suatu komunitas ikan. Semakin merata sebaran individu antar species maka keseimbangan komunitas akan semakin baik. Nilai dominansi (C) tertinggi terdapat di site Hall Batuangus $(0,292)$ dan terendah di site Magic Rock $(0,115)$ (Gambar 13). Nilai Dominansi (C) bekisar antara 0 hingga 1 dimana apabila nilainya mendekati 1 menunjukkan terjadinya dominasi species, begitu juga jika nilainya mendekati 0 dimana tidak ada dominasi oleh salah satu species (Setyobudiandy et al., 2009 dalam Latuconsina et al., 2012).

Hasil penelitian menunjukan semua lokasi masuk dalam kategori dominansi rendah, hal ini menunjukkan tidak adanya dominansi oleh salah satu species ikan karang di lokasi penelitian. Hal ini sesuai dengan pendapat Odum (1993) dimana indeks keanekaragaman $\left(H^{\prime}\right)$ dan kemerataan ( $E$ ) bersifat terbalik dengan indeks dominansinya. Nilai $H^{\prime}$ dan $E$ yang tinggi menunjukkan tingkat dominansi yang rendah. Meskipun di TWA Batuangus tidak ada lokasi yang memiliki keanekaragaman yang tinggi dimana komunitas ikannya rentan karena komunitasnya di semua site tergolong tertekan hingga labil.

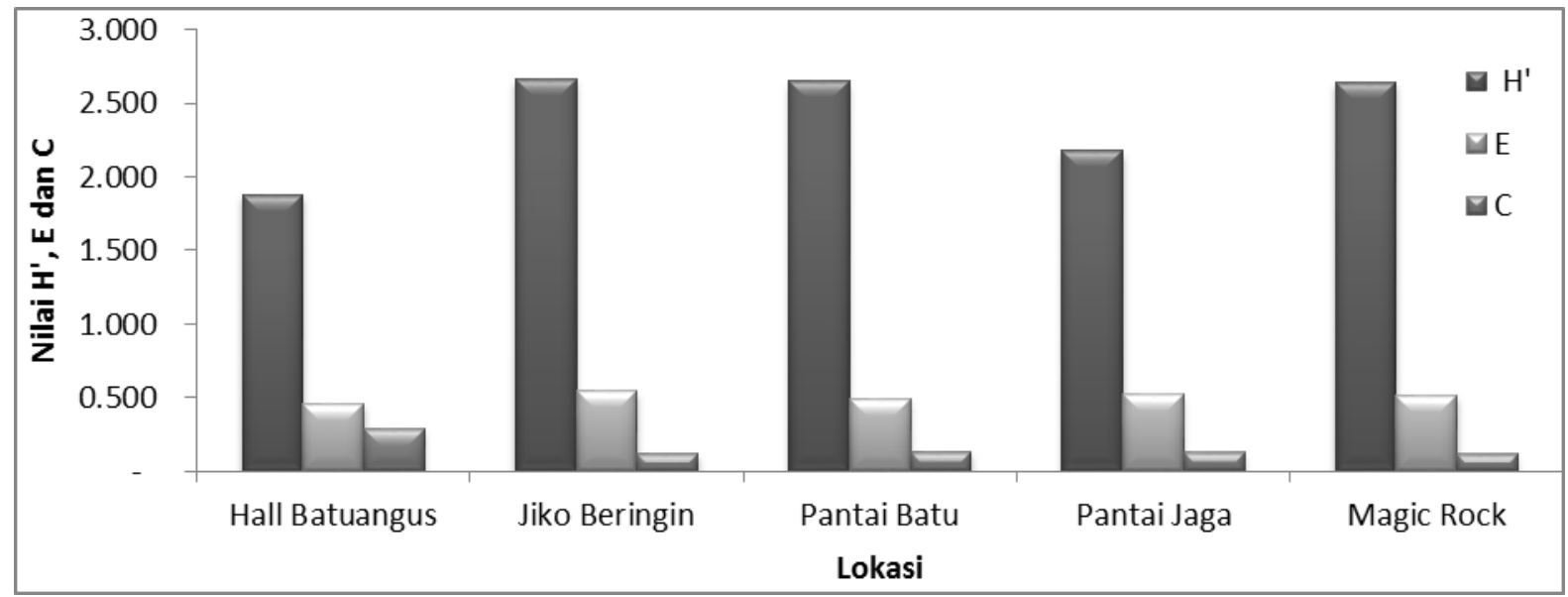

Gambar 9. Indeks ekologi (H', E dan C) di area sekitar TWA Batuangus

\section{Kesamaan species ikan karang}

Pada taraf penskalaan dendogram $70,6 \%$ yang merupakan nilai rata-rata dari indeks similaritas antar stasiun diperoleh 2 kelompok komunitas. Kelompok komunitas pertama adalah site Pantai 
Jaga, Magic Rock, Pantai Batu dan Jiko Beringin, sedangkan kelompok kedua yaitu site Hall Batuangus (Gambar 10). Pengelompokkan ini menunjukkan bahwa terdapat perbedaan komposisi species ikan karang antar groupnya. Site Hall Batuangus terpisah dengan site lainnya karena karakteristik lokasi yang berupa teluk semi tertutup dimana kelimpahan ikan maupun karangnya yang terbatas karena sirkulasi arus yang tidak masuk kedalam teluk yang menjadikan pembatas distribusi karang dan ikan yang ada di dalamnya.

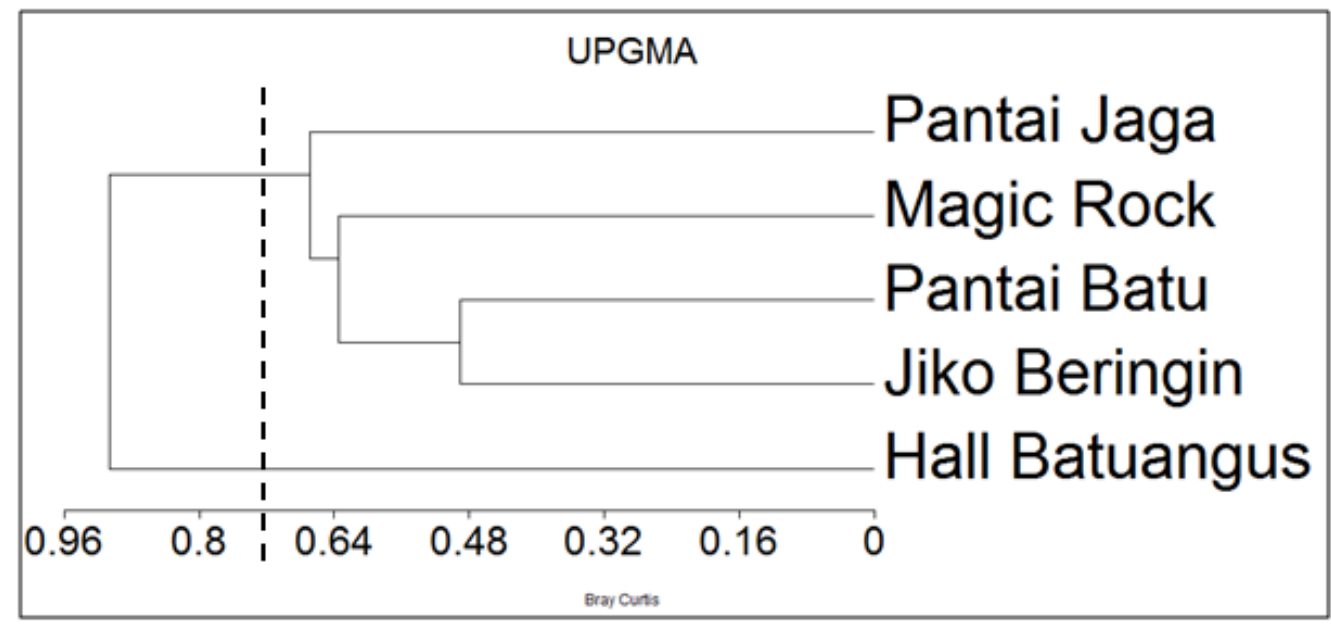

Gambar 10. Dendogram analsisis klaster pengelompokkan komunitas ikan karang di TWA Batuangus

\section{KESIMPULAN DAN SARAN}

Hasil yang didapat dari survei dapat disimpulkan antara lain:

1. Tutupan karang hidup berdasarkan KEPMEN LH No 4. Tahun 2001 tentang kritaeria baku kerusakan terumbu karang, hasil yang didapatkan menunjukan umumnya kondisi tutupan karang di TWA Batuangus umumnya berada pada kategori sedang. Genus karang yang tercatat masuk di dalam transek sebanyak 33 genus yang terdiri dari 27 genus karang keras dan 6 genus karang lunak.

2. Ikan karang yang dicatat/ditemukan dalam survei derah dangkal ini terdiri dari 195 species ikan karang yang termasuk dalam 37 famili (lampiran 1). Lokasi di dalam TWA Batuangus yang memiliki kondisi relatif baik yaitu di lokasi Pantai Batu dimana memiliki kelimpahan dan biomassa terbaik dibanding lokasi lainnya.

3. Struktur komunitas ikan karang berdasarkan indeks ekologinya berada dalam kondisi labil ( $\mathrm{H}^{\prime}$ masuk rendah hingga sedang, E tertekan hingga labil dan $\mathrm{C}$ yang rendah).

4. Kesamaan species ikan karang mengelompokkan site Hall Batuangus terpisah dengan site lainnya karena karakteristik lokasi yang berupa teluk semi tertutup dimana kelimpahan ikan maupun karangnya yang terbatas karena sirkulasi arus yang tidak masuk kedalam teluk yang menjadikan pembatas distribusi karang dan ikan yang ada di dalamnya.

5. Saran dalam penelitian ini yaitu menambah jumlah titik sampling sehingga dapat mewakili seluruh wilayah baik di dalam TWA Batuangus maupun lokasi kontrol.

\section{UCAPAN TERIMA KASIH}

Penulis mengucapkan terima kasih yang sebesar-besarnya kepada Kepala BKSDA Provinsi Sulawesi Utara Bapak Sudiyono atas dukungannya dalam kegiatan penelitian ini. Peneliti juga menghaturkan terima kasih yang sebesar-besarnya kepada staff BKSDA Provinsi Sulut atas dukungannya selama di lapangan dan penyelaman. 


\section{DAFTAR PUSTAKA}

Adrim, M. (2007). Komunitas ikan karang di perairan Pulau Enggano, Provinsi Bengkulu. Jurnal Oseanologi dan Limnologi Di Indonesia, 33, 139-158.

Adrim, M., Hutomo, M., \& Suharti, S. R. (1991). Chaetodontid fish community structure and its relation to reef degradation at the Seribu Island reefs, Indonesia. In: Alcala, A. C. (ed): Proceedings of the regional symposium on living resources in coastal areas. Manila, Philippines: 163-174.

Bohnsack, J. A., \& Harper, D. E. (1988). Length-weight relationships of selected marine reef fishes from the southeastern United States and the Caribbean. NOAA Technical Memorandum NMFS-SEFC-215, 31p.

English, S., Wilkinson, C., \& Baker, V. (1997). Survei manual for tropical marine resources (2nd edition). Australian Institute of Marine Science. Australia. $x+390 p$.

Froese, R., \& Pauly, D. (2010). FishBase. World Wide Web electronic publication. www.fishbase.org, version (11/2010). [15 Juli 2013].

Hill, J., \& Wilkinson, C. (2004). Methods for ecological monitoring of coral reefs: a resource for managers. Australian Institute of Marine Science and Reef Check, Australia.

Kepmen Lingkungan Hidup No. 4 (2001). Kriteria baku kerusakan terumbu karang. Jakarta. Indonesia. $11 \mathrm{p}$.

Krebs, C. J. (1989). Ecological methodology. University of British Columbia. Harper Collins Publisher. 645p.

Kulbicki, M., Guillemot, N., \& Amand, M. (2005). A general aproach to length-weight relationships for New Caledonian lagoon fishes. Journal Cybium, 235-252.

Latuconsina, H., Nessa, M. N., \& Rappe, R. A. (2012). Komposisi spesies dan struktur komunitas ikan padang lamun di Perairan Tanjung Tiram-Teluk Ambon Dalam. Jurnal IImu dan Teknologi Kelautan Tropis, 4(1), 35-46.

Ludwig, J. A., \& Reynolds, J. F. (1988). Statistical ecology: a primer on methods and computing. John Wiley \& Sons, New York: xviii $+337 \mathrm{hlm}$.

Marnane (2003). Laporan Teknis Survei 2003-2004 Di Kepulauan Karimunjawa, Jawa tengah. WCS. $75 \mathrm{p}$.

Odum, E. P. (1971). Fundamental of ecology. W. B. Saunders co., Philadelphia: 574p.

Terangi (2004). Panduan pengenalan ikan karang visual Indonesia. Terangi. 24 hal. 